\title{
Recurrent NK-Cell Lymphoma, Unclassifiable
}

National Cancer Institute

\section{Source}

National Cancer Institute. Recurrent NK-Cell Lymphoma, Unclassifiable. NCI Thesaurus.

Code C157689.

The reemergence of NK-cell lymphoma, unclassifiable after a period of remission. 